\title{
CONFERENCE PAPERS
}

The International Conference "Perspectives of Business Law in the Third Millennium" is organized each year by the Department of Law at Bucharest University of Economic Studies together with the Society of Juridical and Administrative Sciences. The Conference is a platform of international legal debate that examines recent developments and prospects for development of business law. More information about the conference can be found on the official website:www.businesslawconference.ro.

In the current issue of Acta Juridica Hungarica five articles presented at the third edition of the conference that was held on 15 to 16 November 2013 at Bucharest University of Economic Studies are included. 


\title{
Principles of the Exercise of the European Union Competences
}

\author{
EMILIAN Ciongaru
}

\begin{abstract}
The fundamental principles involved in construction of the European Union are at the basis of establishing the prerogatives of the European Union and its Member States. The objective of this study is to present and analyze the evolution of matters that have been taken into account when delimiting the area of competence of the European Union in relation to Member States, as well as to determine the relationships between them, and furthermore establish the manners of settling potential misunderstandings as a result of the activities performed by their bodies. For this purpose, the evolutions of the constitutive treaties of the European Union have been studied, especially the Maastricht Treaty, as it was this one that established the initial distribution of prerogatives between the European Union and Member States. The results of the study consist in an analysis of the exercise of the Union's prerogatives considering that, currently, through the amendments made to the Lisbon treaty a precise classification is made for the first time in the constitutive treaties, separating the main prerogatives into exclusive, joint and supporting prerogatives. The implications of this study include the forming of a general conviction regarding the fact that exercising the competences of the Union is governed by the principles of subsidiarity and proportionality as stated in Art. 5 of the Treaty on the European Union.
\end{abstract}

Keywords: prerogatives of the European Union, the principles of the construction of the European Union, exercise of the prerogatives, the principles of subsidiarity and proportionality

\section{INTRODUCTION}

After an analysis of the relationship between the national competences and those of the European Union resulting from the provisions of European Union Treaties (Boulouis 1995: 113) and jurisprudence of the European Court of Justice, ${ }^{1}$ the following principles and rules evolve: according to the principle of conferral of competences, all competences that have not been conferred to the European Union shall remain reserved for member states; in general, the competences conferred to the Union are concurrent competences; the member state reserves the right to render legitimate or assume conventional undertakings with thirdparty states (Munteanu 1996: 234) as long as and to the extent EU authorities have not intervened yet in such domain.

Only the effective exercise of the Union competences progressively excludes the national competence, this solution being the only one compatible with the attribution of competences and capable of eliminating the risk of a legal void resulting from a legislative deficiency of the European Union; there are also domains where states keep their own competence (Mazilu 2007: 68-69), such as the adoption of regulations on the defense of public order, morality and public safety, cooperation in the field of environmental matters

1 CJCE, hot. din 26 octombrie 1982, Hauptzollamt Mainz c. Kupferberg \& Cie., aff.104/81, Rec. p.3641, (cf. al. 13-14).

Emilian Ciongaru, Ph.D., Associate Scientific Researcher, Institute of Legal Research "Acad. Andrei Radulescu", Bucharest, Romania. E-mail: emil_ciongaru@yahoo.com

(Received: 29.01.2014; revision received: 26.03.2014; accepted: 14.04.2014.) 
corroborated by the Union and in the field of development; there are several domains where competences exclusively belong to the European Union. The specific domains where States have lost their own competence and can only act based on a special authorization from the European Union include cases of domains of common European interest such as creation of the internal market, relations of the Union with third party states or the measures for the preservation of marine resources, and cases where the measures taken by states are subjected to the Union's authorization and control and national measures refer only to the enforcement of the European Union decisions.

From the jurisprudence of the European Court of Justice we may notice that the interpretation of provisions from the treaties on competence is not restrictive (Manin 1993: 63). Though they speak of specialized organizations, they also acknowledge the so-called implicit competences which are not expressly provided by the treaty but which may be deduced by an extinctive and global interpretation taking into account the fulfillment of the object of treaty. This interpretation may be made when the treaty provisions provide an exemplifying enumeration of some domains where the Union is given competence and others which are not forbidden. For example, it is envisaged that if the Union is responsible for the fulfillment of some internal objectives their competence may also be extended to the external domain (Flaesch-Mougin 1993: 352-396) for those measures that are necessary for the good fulfillment of attributions at an internal level. At the same time, the jurisprudence of the Court held that the provisions of treaties on the Union's competences must be given a more extensive than restrictive interpretation, ${ }^{2}$ such as the domain of professional training, where the Union does not have expressly provided competences.

Thus, in order to establish the competences of the European Union and member states (Filipescu-Fuerea: 2000: 141), one must start from the basic elements of the Union construction where, on one hand, it must be envisaged that the European Union exercises competences that are conferred to it by the constitutive treaties and, on the other hand, one must take into consideration the fact that the member states of the Union go on keeping a series of domains where they have exclusive competences, a situation that inevitably leads to the need to delimitate the domains of competence of such entities, the determination of relationships between them and the establishment of ways of settlement of the disputes that may arise following the activities carried out by the bodies thereof.

\section{CLASSIFICATION OF THE EUROPEAN UNION COMPETENCES}

The Lisbon Treaty (Jinga 2008: 15) clarifies the distribution of competences between the European Union and its member states. Thus, the Treaty on the Functioning of the European Union $^{3}$ organizes the functioning of the Union and establishes the domains, limits and conditions relating to the exercise of its competences (Savu 2008: 24) and introduces for the first time a precise classification by which three main competences are differentiated:

- exclusive competences - article 3 from the Treaty on the Functioning of the European Union provides that only the European Union may promulgate and adopt mandatory acts in the following domains: the customs union, establishing the norms on the competition necessary for the functioning of the internal market, the monetary policy for

2 CJ - Hot Casagrande (03.07.1974, 9/74, 773); Granier (13.02.1959; 292/83, Rec. p. 606).

3 The Treaty on the Functioning of the European Union was concluded in Rome on March $25^{\text {th }}$ 1957. 
member states whose currency is the euro, the preservation of biological resources of the sea within the common policy on fishing, and the common commercial policy. The competence of the Union is exclusive in terms of concluding of an international agreement if it is provided by a legislative act of the Union, or it is necessary to allow the Union to exercise its internal competence or if this may bring prejudice to the common norms or modify the domain of their enforcement (Voicu 2009: 222). The role of member states (Tinca 2002: 6) is thus limited to the enforcement of these acts, except in those cases where the European Union authorizes them to adopt certain acts by themselves;

- shared competences - article 4 from the Treaty on the Functioning of the European Union authorizes the European Union and member states to adopt mandatory acts in the following domains: the internal market, the social policy for the aspects defined in the treaty, the economic, social and territorial cohesion, agriculture and fishing (except with respect to the preservation of biological resources of the sea), the environment, consumer protection, transportation, the trans-European networks, the energy sector, the liberty space, security and justice, the common security objectives in terms of public health for the aspects defined in the treaty. Moreover, in the fields of research, technological development and space, the Union has competence to carry out actions especially in respect of the definition and enforcement of programmes, and the exercise of such competence may not result in the prevention of member states from exerting their own competence. In the domains of cooperation for development and humanitarian aid, the Union has competence to take actions so as to lead a common policy, but the exercise of such competence may not result in the prevention of member states from exerting their own competence. Despite all these considerations, member states may exert their own competence only to the extent to which the European Union has not exerted or has decided not to exercise its own competence.

- supporting competences - article 6 from the Treaty on the Functioning of the European Union provides that the European Union may only intervene to support, coordinate or complete the actions of member states in the following domains: the protection and improvement of peoples' health, industry, culture, tourism, education, professional training, youth and sports, civil protection and administrative cooperation. Consequently, it does not have legislative power in these domains or the authority to get involved in the exercise of competences that are incumbent upon the member states.

Apart from these general competences, the European Union also has a series of special competences in certain domains as follows:

- coordination of the economic and employment policies - article 5 from the Treaty on the Functioning of the European Union provides that the European Union has the competence to take steps to coordinate policies regarding the employment of member states' labour force, mainly by defining the orientations of such policies; it may adopt initiatives to ensure the coordination of social policies of member states. Thus, it must define the orientations and guidelines to be followed by member states.

- competences in Foreign Affairs and Security Policy - article 24 from the Treaty on the Functioning of the European Union provides that the European Union has the competence in all domains relating to Foreign Affairs and Security Policy - FASP. It defines and implements this policy via, among others, the President of the European Council and the High Representative of the Union for Foreign Affairs and Security Policy whose roles and status have been recognized by the Treaty of Lisbon. However, the European Union may not adopt legislative acts in this field. In addition, the Court of Justice does not have competence to give judgment in this area. The member states are informed and consult each 
other within the Council regarding any issue related to foreign affairs and security policy having a general interest so as to make sure that the influence of the Union is exerted as efficiently as possible by means of concerted and convergent action (Leicu 1998: 147).

- the flexibility clause - article 352 from the Treaty on the Functioning of the European Union provides that the European Union may act beyond the power of action conferred upon it by the Treaties if the objective pursued so requires. However, this clause is framed with a strict procedure and certain restrictions in terms of its application.

The exercise of Union competences is subject to three fundamental principles which appear in article 5 from the Treaty on the Functioning of the European Union. The delimitation of Union competences is governed by the principle of conferral and the exercise thereof is governed by the principle of subsidiarity and the principle of proportionality as follows:

- the principle of conferral: the Union has only the competences conferred upon it by the Treaties;

- the principle of proportionality: the exercise of European Union competences may not exceed that what is necessary to achieve the objectives of the Treaties;

- the principle of subsidiarity: for shared competences, the European Union may intervene only if it is capable of acting more effectively than the Member States.

\section{PRINCIPLE OF CONFERRAL OF COMPETENCES}

Since the dynamism of European accession determines permanent modifications that prevent the establishment of a final list of competences, the European Union may not apply the classical system of conferral of competences used by the federal states, where they clearly know what the attributions of federal states are and what the attributions of the states making up the federation are.

By virtue of the principle of conferral, the European Union acts within the limits of the competences conferred to it by the member states to attain the established objectives. Any other attribution non-conferred to the Union shall belong to the member states.

The European Union does not have, as member states do, unlimited competences but only those which were conferred to it by the constitutive Treaties; competences that circumscribe the notion of integration and achievement of a common market (FilipescuFuerea 2000: 131) and progressive harmonization of the economic policies of member states.

To fulfill the goal for which it was created, the European Union practically has functional competences corresponding to the powers and means of action conferred in this respect. Each institution of the Union acts within the limits of attributions provided under the constitutive treaties. This means that such institutions may only exert those competences conferred to them by the respective treaties.

The particularity of construction of the Union consists in the fact that we do not see a general conferral of competences, however, there are specific competences (expressly provided in the constitutive treaties), subsidiary competences (created by the acts modifying the constitutive treaties) and implicit competences (created by the Court of Justice of the European Union in the application and interpretation of treaties).

The European doctrine mentions that such competences - being conferred to the European Union - are subject to the principle of specialization, which is a condition of validity for any legal entity. 
As for the time factor, the Court of Justice of the European Union has decided that the conferral of competences is irreversible and final being tightly connected to the duration of existence of Union construction and the concept of integration (Tinca 2002: 5). This way, there is a real transfer of competences from member states to the Union; a transfer made by member states (Marcu-Diaconu 2002: 304) from the internal rule of law for the benefit of the Union rule of law, triggering a definitive limitation of their sovereign rights.

There really is an act of transfer of competences since states do not lose their regulatory capacity, but in very rare cases the regulatory competence exclusively belongs to the Union, and usually the regulatory capacity of states has remained concurrent to that conferred to the European Union.

This solution is the only one compatible with the conferral of competences by different categories of action leaving the choice and date dependent on the opportunity and size of Union intervention. It may be noticed that the doctrine and practice underline how the character of Union competences are concurrent to those of the state and, concerning the act of conferral or transfer of competences, it has also been affirmed that one may speak of a transfer under the suspensive condition of Union exercise. The alleged transfer of competences represents for the state rather a joint (Marcu-Diaconu 2002: 218) exercise of competences within an international structure than a veritable relinquishment.

\section{THE PRINCIPLE OF PROPORTIONALITY}

The principle of proportionality says that the Union's actions shall not exceed that what is necessary to attain the objectives provided under the treaty. This principle has been applied in the jurisprudence of the Court of Justice of the European Union ever since $1956^{4}$ being considered as one of the principles resulting from the nature of the Union, which is inherent to the notion of common market (Jacque 2001: 108).

According to this principle, the Union's institutions shall act in such a way so as not to exceed in the exercise of their competences what is necessary to attain the Union's objectives. When the institution may choose among several variants regarding the settlement of its attributions, based on this principle, it shall choose the less restrictive one and, in the cases where certain tasks are imposed, these must not be disproportionate in relation to the envisaged goals.

This principle may be found especially in the enforcement of certain sanctioning measures of an administrative or criminal nature as well as in the field of internal consumer protection from member states or the free movement of individuals. The principle shall apply both for the Union's measures and national measures providing for the sanctioning of violations of European Union legal norms.

The principle of proportionality means that any measure taken by a public authority affecting the rights of individuals must be adequate, necessary and the most reasonable for the attainment of a legitimate goal.

The principle of proportionality is generally invoked in legal procedures where the issue of prevalence of a certain legal right over another legal right is in question or where the dispute refers to the protection of a private right in contrast to protecting of the public interest.

${ }^{4}$ CJ - Hot Kramer (14.07.1976, 3, 4 et 6/76, 1279). 
In such a context, the principle of proportionality is that conflict rule which determines the tilting of scales in favour of one party, and it is an analytical procedure which does not affect the application of substantive (Harbo 2010) norms.

In this analysis, they try to establish whether such a rule of law passes the test of relation quality between means and goal.

Subsequently, they must check whether such a measure is also necessary for the pursued objective and, being most important, if it is the least restrictive of all possible administrative measures to attain the envisaged goal. This last criterion is the most sensitive one; being capable of orienting judgment in one direction or another.

The Court of Justice has evaluated the abuse of law in light of the principle of proportionality by weighing the right of Union citizens to rely on certain fundamental liberties in order to identify some more favorable arrangements in other member states, on the one hand, and identify the interest of the member states in protecting themselves against abuses, on the other hand.

When evaluating the legality of a measure in light of the criterion of the principle of proportionality, the European Court of Justice is less prone making differentiations according to the manner and form of action adopted by such an authority (Schwartze 1992: 862).

\section{THE PRINCIPLE OF SUBSIDIARITY}

The principle of subsidiarity in the field of European Union competences means that it does not intervene in the domains that do not belong to exclusive competence unless the envisaged objectives may not be adequately attained by member states and they may be better fulfilled at the Union (Filipescu-Fuerea 2000: 146) level based on the reasoning that what can be achieved individually by each state should not be made jointly, but if this individual fulfillment is not possible then collective intervention is required.

Subsidiarity provides some orientation for the manner in which these competences should be exerted at the Union level - being a dynamic concept that allows for the expansion of action of the European Union - within the limits of its competences, when circumstances require it, and vice-versa; their limitation and non-exercise when they are no longer justified. ${ }^{5}$ Subsidiarity - a principle being clearly elated to the concurrent competences of the States and the Union and the effective exercise of regulatory power by the state - is under a suspensive term to the extent that priority is given to the regulations of the Union without losing them in their materiality and in the prerogatives it has, first of all jus imperii meaning to decide or regulate peremptorily (Predescu-Predescu-Roibu 2001: 105). Like most community solutions, subsidiarity is more of a de facto than de jure situation being concordant with prudent pragmatism which characterizes the European development model.

This principle was introduced as a general principle by the Maastricht Treaty and this circumstance is due to the fact that this principle is tightly connected to the democratic deficit (Galea-Dumitrascu-Morariu 2005: 115), which is attempted to be reduced by regulating the exercise of competences. In this respect, it represents a principle aimed at eliminating some excesses in terms of legislation.

5 The protocol on the application of Subsidiarity and Proportionality annexed to the Amsterdam Treaty, point 3. 
The principle of subsidiarity was debated within meetings of the European Council in 1992 when the guidelines were established that were capable of correctly appreciating, from one case to another, weather a measure taken by a body of the Union was concordant with this principle, or not. Thus, it has been shown that for its application the national identity of member states and their national competences must be observed.

At the same time, the European Union must act to attain the goal thereof being unable to give these attributions only over to the states, even more so as they may not be adequately fulfilled.

The protocol on the application of Subsidiarity and Proportionality is annexed to the Amsterdam Treaty and provides that each institution, in the exercise of its competences, supervises the observance of the principle of subsidiarity, and the application of the principle of subsidiarity does not bring prejudice to the principles established by the Court of Justice in terms of the relationship between National Law and European Union law. It also stipulates that the principle of subsidiarity does not dispute the competences conferred to the European Union by the treaty as they are interpreted by the Court of Justice (Chilea 2001: 172). The combination of the Union's interest with the principle of subsidiarity can be referenced in the manner of action of European institutions in order to elaborate the derived European law (Filipescu-Fuerea 2000: 36) and the Court jurisprudence.

\section{CONCLUSIONS}

The as precise as possible establishment of competences in the European Union represents a very complex issue since reasons are based both on the heterogeneous character of member states of the European Union and the distribution of competences between the Union and the states. Mention must be made of the fact that, especially among the decisionmaking institutional structures of the Union, there is permanent competition for power and prestige, a process favored both by the system of distribution of competences and the advantages held by those involved in the administration thereof; such competition is beneficial most of the time with regard to European integration, the Union policies being a product of this tension.

The principles on which the exercise of European Union competences relies are considered to be genuine instruments for the exercise and decentralization of political power within the European union where the member states have given up some part of their national sovereignty to the Union structures but, at the same time, in each member state there are governmental mechanisms for the administration of national laws. In general, these principles mean that decisions should be made at the lowest level of competence in the political hierarchy and the center may intervene only when it is absolutely necessary. Democracy must rely on a clear separation between the national and supranational power. Member states must enjoy an as big as possible power in the sectors where neither the Union nor the member states have an exclusive competence. The European Committee relies on the principle that a domain exclusively belongs to the competence of the European Union when a treaty requires the Union's institutions to act. European confrontations from recent years have always disputed the relations between the member states of the Union and the institutions thereof. It is shown that if these relations are built based on the cooperation of member states, and European institutions observe the principle of subsidiarity with the necessary rigour, the new construction will be united and sustainable. In exchange, if they continue subordinating the member states and people to the bureaucratic apparatus of Brussels, by seeking to even impose new geography and new border checkups, the design 
of this construction will fail just like in previous attempts. The questions as to whether those who go on this line know about the other projects of the European Union and whether it is not necessary for each nation to designate the proper individuals who have a solid culture in the field, in respect of the conditions in which the member states would have or would fulfill any role from this viewpoint, naturally arise.

\section{REFERENCES}

Boulouis, J. (1905): Droit institutionel de l'Union européenne. Montchrestien, 5-eme éd.

Chilea, D. (2001): Dreptul Uniunii Europene. Constanta: Muntenia\&Leda.

Filipescu, I. P.-Fuerea, A. (2000): Drept Comunitar Institutional. Bucharest: Actami.

Flaesch-Mougin, C. (1993): Le Traité de Maastricht et les compétences externes de la Communauté européenne: à la recherche d'une politique externe de l'Union. Cahiers de droit européen, no. 3-4.

Galea, I.-Dumitrascu, M. A.-Morariu, C. (2005): Tratatul instituind o Constitutie pentru Europa. All Beck, Bucharest.

Harbo, T.-I. (2010): The Function of the Proportionality Principle in EU Law. European Law Journal, vol. 16.

Jacque, J. P. (2001): Droit internationnel de l'Union Europeenne. Paris: Dalloz.

Jinga, I. (2008): Tratatul de la Lisabona: solutie sau etapa in reforma institutionala a Uniunii Europene? Revista Romana de Drept Comunitar, no. 1.

Leicu, C. (1998): Drept comunitar. Bucharest: Lumina Lex.

Manin, P. (1993): Les communautés européennes. L'Union européenne. Droit institutionnel. Paris: A. Pedone.

Marcu, V.-Diaconu, N. (2002): Drept comunitar general. Lumina Lex, Bucharest.

Mazilu, D. (2007): Integrarea Europeana. Drept Comunitar si Institutii Europene. 5th ed., Bucharest: Lumina Lex.

Munteanu, R. (1996): Drept European. Evolutie, institutii, ordine juridical. Bucharest: Oscar Print.

Predescu, B.-Predescu, I.-Roibu, A. (2001): Principiul subsidiaritatii. Official Journal Autonomous Administration, Bucharest.

Savu, T. (2008): Obiectivele si competentele Uniunii Europene consacrate de Tratatul de la Lisabona. Revista Romana de Drept Comunitar, no. 1.

Schwartze, J. (1992): European Administrative Law. Sweet and Mawell: Office for official publications of the European Communities.

Tinca O. (2002): Drept Comunitar General. 2nd ed. Bucharest: Didactica si Pedagogica.

Voicu, M. (2009): Uniunea Europeana inainte si dupa Tratatul de la Lisabona. Bucharest: Universul Juridic. 